\title{
External Relations and the EAC
}

\author{
Leonard Obura Aloo
}

\subsection{Introduction}

An important element of co-operation between states is co-operation in external relations. In this Chapter some aspects of the external relationships of the East African Community (EAC) will be addressed. The relationships between the East African Community, other international organisations and states will be considered. Some comments will be made about the relationship between the Community and its Partner States. To begin with the Chapter considers the Community's capacity to enter into external relations or its external competence. The EAC coordination of Partner States' positions in foreign relations, defence and trade matters will then be considered. Given its significance, the Chapter will briefly address trade negotiation between the EAC and the European Union (EU). A comment will be made about the EAC's relations with the African Union and other regional economic communities. The Chapter concludes by evaluating the extent of the EAc's external competence.

\subsection{External Competencies of the East African Community}

\subsubsection{The East African Community Acting Directly in External Relations}

The objectives of the EAC are to develop policies and programmes aimed at widening and deepening co-operation among the Partner States in political, economic, social, and cultural fields, research and technology, defence, security and legal and judicial affairs. ${ }^{1}$ The ultimate goal of the EAC is a political federation. ${ }^{2}$ For these goals to be achieved, there is an inevitable demand that the Partner States transfer or surrender some level of sovereignty to the EAC and its institutions. ${ }^{3}$ Coordination presupposes some level of joint action. In

1. EAC Treaty Article 5(1).

2 EAC Treaty Article 5(2).

3 Oppong, R.F. "Re-imagining International Law: An Examination of Recent Trends in the Reception of International Law Into National Legal Systems in Africa” 30 Fordham Int'l L.J. 296 (2006) 299 . 
relations with external parties it presupposes that the organisation will have some level of capacity to interact with the third parties, in other words that the organisation will have external legal capacity. There is considerable debate about the exact nature of the international legal personality of inter-governmental organisations.

Coordination in the external relations of EAC states is not a new development. Under the defunct EAC, for example, Tanzania, Uganda and Kenya, in 1969, entered into an agreement-the Arusha Agreement-with the then European Economic Community. ${ }^{4}$ This Agreement granted certain concessions regarding access of goods from Tanzania, Uganda and Kenya to the European Economic Community. ${ }^{5}$ The tradition of entering into external agreements has continued into the current treaty arrangements. The question that remains is, to what extent can the Community enter into external arrangements and are those arrangements binding on the Partner States and what governs the Community's capacity to enter into these arrangements? To address these questions, the legal personality of the Community and its functions and powers need to be examined.

A reading of the current Treaty for the Establishment of the East African Community (the EAC Treaty) does not reveal a clear provision conferring upon the EAC a general competence with regard to foreign agreements. Article 138(1) of the EAC Treaty accords the EAC international legal personality. ${ }^{6}$ This provision is similar to Article 47 of the Treaty on European Union, which explicitly recognises the legal personality of the EU. ${ }^{7}$ However, Article 138(1) of the EAC Treaty appears to be pointed internally at the Partner States of the EAC. This internal outlook is suggested by both its full title 'Status, Privileges and Immunities' and its content in dealing with headquarter agreements and immunity of staff. ${ }^{8}$ Article $138(1)$ of the EAC Treaty, therefore, covers the privileges and immunities of the EAC within the territory of the Partner States rather than the EAC's capacity to enter into external

4 Agreement establishing an association between the United Republic of Tanzania, the Republic of Uganda and the Republic of Kenya and Annxed Documents, Brussels, 1969. See also Mukwaya, A.K.K. "A Survey of Relationships between the European Union and the East African States", 1961-1980. East Afr. Geogr. Rev Vol 19, No. 2 pp. 73092, 1997.

5 Cosgrove-Twitchett, C. Europe and Africa: from association to partnership. Surrey: Saxon House 1978 p. 146; see also Zartman, W. The Politics of Trade negotiations between Africa and the European Economic Community. Princeton, Princeton University Press, 1971.

6 EAC Treaty Article 138(1).

7 Article 47 Treaty on European Union. See also EU Chapter 5 on the external standing and competences of the $\mathrm{EU}$.

8 EAC Treaty Article 138(2) and (3). 
relationships. This 'internal' orientation is also seen in Article 4(1) of the EAC Treaty which indicates that the Community shall have capacity, within each of the Partner States, of a body corporate with perpetual succession, and shall have power to acquire, hold, manage and dispose of land and other property, and to sue and be sued in its own name. ${ }^{9}$

Although Article 4(1) of the EAC Treaty indicates that the EAC can sue and be sued in its own name, the Partner States undertake under the Treaty to grant the Community and its officers the privileges and immunities accorded to similar international organisations within the Partner States' territory. ${ }^{10}$ There is thus an apparent paradox with the EAC Treaty indicating, on the one hand, that the EAC can sue and be sued in its own name while, on the other hand, requiring the Partner States to grant the EAC similar immunities as accorded to international organisations.

Article $4(2)$ of the EAC Treaty provides that:

... the Community shall have powers to perform all the functions conferred upon it by this treaty and to do all things, including borrowing, that are necessary or desirable for the performance of those functions. ${ }^{11}$

Article 9(4) indicates that the organs and institutions of the Community shall perform the functions, and acts within the limits and powers conferred upon them by or under the Treaty. ${ }^{12}$ This restrictive framing has, however, not prevented the EAC from activities in external relations. The argument may be made that an inter-governmental organisation can derive its competence from a wider reading of its respective treaty. It has been argued by Fin Seyersted that the legal capacity of an inter-governmental organisation to perform sovereign and international acts is like those of states-not confined to what can be positively deduced from their constitutions but comprises all acts which are not precluded by their constitutions and which do not impose new obligations upon parties who are not subject to their jurisdiction. ${ }^{13}$ However, it is recognised that it is only to the extent that other subjects of international law

$9 \quad$ EAC Treaty Article 4(1).

$10 \quad$ EAC Treaty Article 138(3); article 72(3) requires each partner state to respect the international character of the responsibilities of the institutions and staff of the Community.

11 EAC Treaty Article 4(2).

12 EAC Treaty Article 9(4).

13 Seyersted, F. "Objective International Personality of Intergovernmental Organizations: Do their Capacities Depend Upon The Conventions Establishing Them?" Nordisk Tidsskrift for International Ret 34 p. 3. 
recognise a regional body as a member of the international community that it can take initiatives and play an active role in the international arena. ${ }^{14}$

However, apart from the general aspiration in the statements, the EAC Treaty itself is silent on the actual authority and power of the Community as far as external relations are concerned. ${ }^{15}$

The theoretical arguments notwithstanding, the reality is that the EAC has acted directly, for example the Community has signed development aid agreements with third countries ${ }^{16}$ and has received diplomats. ${ }^{17}$ The Summit, the highest organ of the EAC, can also direct action on behalf of the EAC, for example, designating the Chairperson of the Summit to sign an accession treaty with a new Partner State. ${ }^{18}$ A key example is the decision by the Summit to have the Partner States of the EAC negotiate as a bloc in matter of the African Caribbean and Pacific Countries, European Union (EU) and the World Trade Organisation (WTO) that was arrived at in 2002. ${ }^{19}$

\subsubsection{Co-ordination of Activities of Partner States}

The EAC Treaty requires the Partner States to develop policies and programmes aimed at widening and deepening co-operation among the Partner States in political, economic, social and cultural fields, research and technology, defence, security and legal and judicial affairs for the mutual benefit of the Partner States. ${ }^{20}$ Having provided for the areas of co-operation, the EAC Treaty proceeds to indicate the manner in which this co-operation will be achieved.

14 Mathinjsen, P.S.R.F A Guide to European Union Law. Thomson Sweet \& Maxwell London 2007 p. 491; article 38-39 Vienna Convention on the Law of Treaties.

15 Compare in this regard also the discussion in EU Chapter 5 , as in the EU many of the external competences of the EAC also were derived by the CJEU from the internal competences, as no explicit competences had been granted in the Treaty.

16 For example EAC Grant Agreement with the Federal Republic of Germany signed on the 23rd January 2016 see http://www.eac.int/news-and-media/press-releases/20160123/ eac-germany-sign-37-million-euros-agreement-support-regional-integration.

17 EAC receives Finnish Ambassador see http://www.eac.int/news-and-media/pressreleases/20160122/eac-secretary-general-receives-credentials-finnish-ambassador.

18 East African Community Joint Communique 17th Ordinary Summit of the East African Community Heads of State item 11 see http://www.eac.int/news-and-media/statements/ 20160302/joint-communique-17th-ordinary-summit-east-african-community-headsstate-Directing the Chairperson to sign the accession treaty with South Sudan.

19 See Communiqué of the 6th Extraordinary Summit of East African Community Heads of State held in Arusha on 2oth August 2007 referring to the Summit of April 2002. (Communiqués and other sources refer to the Summit of 14th April 2002, the Communiqué of the Summit is dated 11th April 2002). EAC Treaty Article 5(1). 
Article 5(2) of the EAC Treaty indicates the steps that will be taken in the journey to ultimate Political Federation: the Customs Union, a Common Market and the Monetary Union..$^{21}$ The EAC Treaty then lists the approaches to co-operation: the Fundamental Principles of the Community; the Operational Principles of the Community; and a General Undertaking as to Implementation. ${ }^{22}$ The terms co-operation and co-ordination are recurrent themes throughout these provisions. For example, one of the fundamental principles of the Community is co-operation for mutual benefit, ${ }^{23}$ and one of the operational principles is people centred and market driven co-operation. ${ }^{24}$

The Partner States have given a general undertaking, to amongst other things, pass legislation conferring the Community with legal capacity and personality required for the performance of its functions and to confer the legislation, regulations, and directives of the Community and institutions with the force of law within each Partner States territory. ${ }^{25}$ The Partner States are also required to give Community law precedence over similar national laws in matters covered by the Treaty. ${ }^{26}$

The EAC Partner States have agreed to co-operate in various areas and ultimately to form a political federation. It can be concluded that, at least by their intention, some element of sovereignty has been ceded to the EAC. The classical definition of sovereignty is "independence from authority of any other state and equality with it in international law". 27 To the extent that the Partner States have pooled their decision making there is some ceding of sovereignty. The main responsibility for the achievement of the aims of the EAC is, however, retained by the Partner States who are ultimately in control of the process.

The EAC is a permanent entity that is established for an unlimited period. ${ }^{28}$ The fact that the ultimate aim is a political federation implies that the Treaty will have achieved its aims once a political federation is achieved. It can therefore be argued that the EAC, in the present form, is intended to exist until political federation is achieved. A Partner State can withdraw from the EAC Treaty provided the Partner States National Assembly resolves by not

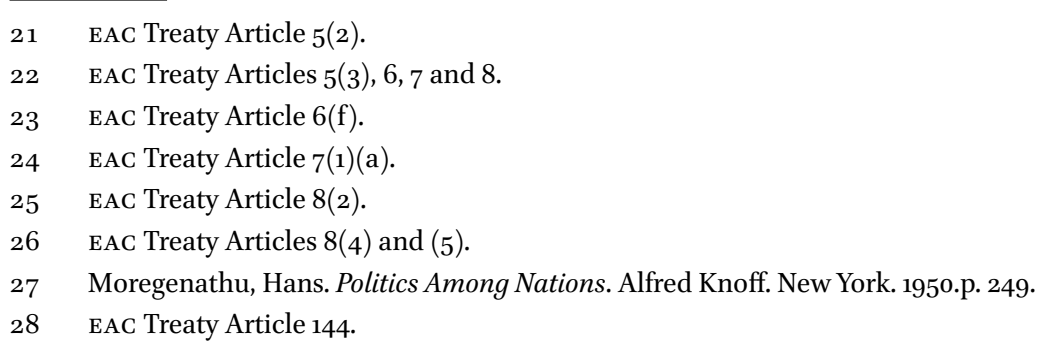


less than two thirds majority of all members entitled to vote and the Secretary General of the Community is given twelve months notice of the intention to withdraw. ${ }^{29} \mathrm{~A}$ Partner State may also be suspended or expelled from the EAC. ${ }^{30}$

The fact that the Partner States are in control can be evidenced by the provision that decision making under the EAC Treaty is largely by consensus. ${ }^{31}$ The main organs of the EAC are: ${ }^{32}$

(a) The Summit comprising head of government of the Partner States that gives general direction towards the realisation of the goals of the Community. ${ }^{33}$

(b) The Council of Ministers which is the main decision making body comprising ministers of the partner states responsible for regional co-operation and such other Ministers as the Partner States may determine. ${ }^{34}$

(c) The Co-ordinating Committee made up of permanent secretaries responsible for regional co-operation. It co-ordinates the activities of the sectoral committees and reports to the Council. ${ }^{35}$

(d) The Sectoral Committees which are established by the Council on recommendation of the respective Co-ordinating Committees. They develop and monitor the implementation of the programmes of the EAC. ${ }^{36}$

(e) The East African Court of Justice

(f) The East African Legislative Assembly

(g) The Secretariat

The Summit decision making process is by consensus. ${ }^{37}$ The consensus approach protects national interests as, effectively a Partner State can veto the decision of the Summit.

Moreover, under the earlier East African Community, the East African Court of Appeal in Okunda v Republic had held that the national constitutions were

\footnotetext{
$29 \quad$ EAC Treaty Article 145.

$30 \quad$ EAC Treaty Articles 146 and 147.

31 EAC Treaty Article 12(3).

32 See summary in Lumumba, P.L.O. "The East African Community Two: Destined to Succeed or Doomed to Fail?" LSKJ 5(1)(2009) pp. 105-132 at p. 121.

33 EAC Treaty Chapter 4.

34 EAC Treaty Chapter 5 .

35 EAC Treaty Chapter 6.

$36 \quad$ EAC Treaty Chapter 7.

37 EAC Treaty Article 12(3).
} 
superior to the provisions of the Treaty. ${ }^{38}$ In this case a prosecution was instituted by the Attorney-General of the Republic of Kenya against two persons under the provisions of the Official Secrets Act of the East African Community without the consent of the Counsel to the Community as required by the Act. Under the Constitution of Kenya, at the time, the Attorney-General controlled prosecutions. There was therefore an apparent conflict between the Constitution of Kenya and the Official Secrets Act of the East African Community. The High Court of Kenya held that the Act of the Community was void to the extent of the inconsistency with the Constitution of Kenya. On appeal, the East African Court of Appeal, which at the time severed all the Partner States of Community held that the Constitution of Kenya was paramount and any law, whether it be of Kenya or the Community, or of any other country which had been applied in Kenya, which was in conflict with the Constitution was void to the extent of the conflict.

The legacy of the East African Court of Appeal decision in Okundav Republic continues to inform the position of EAC laws vis-a-vis the national constitutions. Decisions and actions at the EAC level are controlled by the national constitutional set up. Any authority surrendered to the EAC has to be done, it appears, within the constitutional context of the individual country.

\subsection{Specific Co-operation in Foreign Policy}

The EAC Treaty requires that Partner States establish common foreign and security policies. ${ }^{39}$ The objective of the common foreign and security policies include:

(a) safeguarding the common values, fundamental interests and independence of the Community

(b) strengthening the security of the Community and its Partner States in all ways

(c) developing and consolidating democracy and the rule of law and respect for human rights and fundamental freedoms

(d) preserving peace and international security among the partner states

(e) promote co-operation at international fora, and

$38 \quad$ Okundav Republic [1970] E.A. 453.

39 EAC Treaty Article 123(1). 
(f) enhance the eventual establishment of a Political Federation of the Partner States ${ }^{40}$

The Partner States have bound themselves under the EAC Treaty to co-ordinate actions in international organisations and international conferences. ${ }^{41}$

The co-ordination in this area has been characterised by a cautious approach by the Partner States in yielding sovereignty to the EAC. This is shown by the fact that the implementation of the provisions of the Treaty on co-operation on political matters were to become operative when so determined by the Council. The Treaty also requires the Council to prescribe in detail how this co-operation is to be implemented. ${ }^{42}$ The provisions are not yet operational. The East African Court of Justice (EACJ) has been called upon to consider the justiciability of the provisions of the EAC Treaty on political cooperation. In the case of Attorney General of Uganda v Tom Kyahurwenda the EACJ considered the question and ruled that the provisions of paragraphs 2, 3 and 4 of Article 123 of the Treaty on political co-operation are not justiciable before the EACJ or local courts until the provisions are operationalised. ${ }^{43}$

The EAC currently cites the joint support for citizens of the Community for international level positions as a tangible result of the co-ordination of efforts in the Partner States international relations. ${ }^{44}$ This promotion of a relatively minor achievement of co-ordination indicates the reluctance of the Partner States to yield greater authority to the EAC. A draft protocol on foreign policy co-ordination has been published. ${ }^{45}$ The provisions of the draft protocol further indicate a cautious approach as it calls mainly for collaboration rather than the yielding of any authority to the Community. For example, the draft protocol calls for "collaboration" in diplomatic and consular activities, multilateral diplomacy, and in economic and social activities. ${ }^{46}$ The approach of the draft is cautious and calls for collaboration rather than action by the EAC. Furthermore, caution is emphasised by the fact that the protocol remains a draft and a final version is yet to be concluded.

\footnotetext{
$40 \quad$ EAC Treaty Article 123(3) (a)-(f).

41 EAC Treaty Article 123(4), see also Articles 5, 6, 7, 123, 124 and 125 of the EAC Treaty.

42 EAC Treaty Article 123(5).

43 Attorney General of Uganda v Tom Kyahurwenda Case Stated No. 1 of 2014.

44 www.eac.int/legal/index.

45 Draft East African Community Protocol on Foreign Policy Co-ordination Arusha March 2010.

46 Draft East African Community Protocol on Foreign Policy Co-ordination Arusha March 2010 article 5,6 and 7 .
} 
The EAC has concluded a Protocol on Peace and Security ${ }^{47}$ and a Protocol on Corporation in Defence Affairs. ${ }^{48}$ Notably, these two protocols call for collaboration and do not themselves cede any decision making or action to the Community itself.

In the area of trade negotiations, the co-ordination effort has been institutionalised through the EAC Trade Negotiations Act of 2008.49 The Act was initiated as a private member's bill in the East African Legislative Assembly. ${ }^{50}$ The objectives of the Act include the establishment of joint negotiation of the Partner States in bilateral, regional and multilateral trade. ${ }^{51}$ The Act creates a Commission known as the East African Joint Trade Negotiation Commission which is the mechanism the Partner States use to negotiate as a bloc in matters relating to regional and multilateral trade. ${ }^{52}$ The Joint Trade Negotiation Commission is tasked with conducting trade negotiations on behalf of the Partner States of the EAC. ${ }^{33}$ The Joint Trade Negotiation Commission comprises two members nominated by each Partner State, the Secretary General of the EAC as a ex-offico member, one ex-offico member designated by the designated Ministry of each Partner State. The Director General of the Joint Trade Negotiating Commission is also an ex officio member. ${ }^{54}$

The negotiating mandate of the Joint Trade Negotiating Commission is given in writing by the Summit acting through the Council. ${ }^{55}$ Notwithstanding the existence of the Joint Trade Negotiating Commission, the co-ordination has not been seamless and implementation of the Act has not been a smooth process. ${ }^{56}$ The Partner States still send individual delegations to international trade negotiation forums and enter into multilateral trade agreements as

47 East African Community Protocol on Peace and Security Arusha February 2013.

48 East African Community Protocol on Co-operation on Defence Affairs Arusha April 2012.

49 The East African Trade Negotiations Act of 2008.

50 EALA Achievements 2001-2009 bill initially introduced in $2003 \mathrm{http} / /$ www.eala.org/new/ index.php/the-assembly/achievements.

$5^{1} \quad$ The EAC Trade Negotiations Act of 2008. Section 2.

$5^{2}$ The East African Trade Negotiations Act of 2008. Section 3 and 5 .

53 The East African Trade Negotiations Act of 2008. Section 5(1)(c).

54 The East African Trade Negotiations Act of 2008. Section 6.

55 The East African Trade Negotiations Act of 2008. Section 12.

56 Ayeko, F. "East African States Still Negotiate Trade Pacts as One Despite 2008 Law" The East African Monday, October 42010 http://www.theeastafrican.co.ke/news/EAC\%20 states\%2ostill\%2oto\%2onegotiate\%2otrade\%2opacts/-/2558/1024814/-/9f3mip/-/index .htm. 
individual countries. ${ }^{57}$ There has been apparent reluctance to implement the Trade Negotiations Act. ${ }^{58}$ This could be because, as indicated above, the Act was initiated as a private member's bill and not by the Secretariat or by the Partner States. As will be seen below negotiating with the EU, for example, has seen apparent conflicts between Partner States.

\subsection{EAC and EU Relationships}

As noted above the EAC-EU relationship has a long history dating back at least to the 1969 Arusha Agreement between Tanzania, Uganda and Kenya and the European Economic Community. ${ }^{59}$ In the early 1970s, the three East African countries joined other African, Caribbean and Pacific states in a bloc, the ACP, to negotiate with the European Economic Commission. The negotiations resulted in the first Lomé Convention in 1975 (Lomé I). ${ }^{60}$ The Lomé Convention was renegotiated and renewed three times: the second Lomé II was signed in 1980; Lomé III in $1985 ;{ }^{61}$ and Lomé IV in $1990 .{ }^{62}$ The Lomé Convention's provisions were viewed by other states as being incompatible with the General Agreement on Tariffs and Trade (the GATT) and subsequently the wто. This resulted in complaints filed before the GATT, WTO and also the European Court of Justice. ${ }^{63}$ The Lomé Convention's trade provisions included

57 Ayeko, F. "East African States Still Negotiate Trade Pacts as One Despite 2008 Law" The East African Monday, October 42010 http://www.theeastafrican.co.ke/news/EAC\%20 states\%2ostill\%2oto\%2onegotiate\%2otrade\%2opacts/-/2558/1024814/-/9f3mip/-/index .htm.

58 Seatini. Uganda's Trade Negotiation Framework. September 2013 p. 16.

59 Agreement establishing an association between the United Republic of Tanzania, the Republic of Uganda and the Republic of Kenya and Annxed Documents, Brussels, 1969.

6o The First Lomé Convention Lomé I (Negotiations began in 1973 and lasted for eighteen months. The convention was signed on 28th February 1975 and cam into force on 1st April 1976. See Babarinde, O.A. The Lomé Convention and Development: An Empirical Assessment. Brookfield: Avebury Press 1994 p. 20; Oumar Sy, S. "The Birth of the ACP Group" The Courier No. 93 September- October 1985 pp. 51-56. Full text see The Courier No. 31 Special Issue march 1975 .

61 For full text see The Courier No. 89 January-February 1985.

62 For full text see The Courier No. 120 March-April 1990; Lomé vi bis The courier No. 155 January-February 1996.

63 DS 27 European Communities-Regime for the Importation, Sale and Distribution of Bananas (Complainants: Ecuador; Guatemala; Honduras; Mexico; United States) see https://www.wto.org/english/tratop_e/dispu_e/dispu_status_e.htm; Federal Republic of Germany v Council of the European Union. 
trade preference arrangements including tariff rates that differed from the Most Favoured Nation (MFN) rate and discriminated against other developing countries as it granted more generous treatment than offered by the EU's generalised system of preferences. The regime also had four protectionist protocols on beef and veal, rum, bananas and sugar. ${ }^{64}$

The Lomé Conventions were replaced in the year 2000 with a new agreement, the Contonu Agreement, between the ACP countries and the EU.65 Under Article 36(1) of the Cotonou Agreement, the EU and the ACP countries agreed to negotiate Economic Partnership Agreement (EPAs) which would be compatible with the wTо. ${ }^{66}$

Negotiations between the EAC and EU began immediately, and progressed for over a decade. The EU set 1st October 2014 as a deadline upon which the EAC states would forfeit their preferential treatment and revert to the less generous generalised system of preferences. ${ }^{67}$ The result would be that exports from Kenya to the EU would face higher tariffs while those from the other EAC Partner States would continue to enjoy duty free access to the EU under a component of the EU generalised system of preferences - the Everything But Arms arrangement. ${ }^{68}$

The negotiation of the EU-EAC EPA was concluded in October 2015 and was expected to be ratified by October 2016.69 However, internal timelines have been missed, for instance an expected signing in July 2016 was missed resulting in speculation that the ratification is facing difficulty. ${ }^{70}$ Furthermore, following

64 Grynberg, R. The WTO incompatibility of the Lomé Convention trade provisions Asia Pacific School of Economics and Management Working Paper 1998.

65 Agreement between the ACP and the EC the Contonu Agreement 2000. The agreement was revised in 2005 .

66 Article 36(1) Cotonou Agreement; Gathii, James T. The Cotonou Agreement \& Economic Partnership Agreements.

67 Ongónge, L. "The EAC-EU Economic partnership Agreement: Context, Content and Consequences". Trade Notes. Institute of Economic Affairs. Nairobi 2015.

68 Kenya Human Rights Commission. The ABC of the EAC-EU Economic Partnership Agreement (EPA). Kenya Human Rights Commission. Nairobi; Ongónge, L. "The EAC-EU Economic partnership Agreement: Context, Content and Consequences”. Trade Notes. Institute of Economic Affairs. Nairobi 2015.

69 The European Commission. Economic Partnership Agreement between the EU and the Eastern Africa Community (EAC) October 2015 http://trade.ec.europa.eu/doclib/ $\mathrm{html} / 142194 . \mathrm{htm}$.

70 Ssemuwemba, Anne M. ËPA Negotiations: Is EAC at the crossroad?" The Daily Monitor Tuesday, August 22016 http://www.monitor.co.ug/Business/Prosper/EPA-negotiations-Is-EAC-at-the-crossroads-/688616-3325520-kg1omdz/index.html. 
the vote by Britain to exit the EU in June 2016, the EAC Partner States' position on the future of the EU-EAC EPA appear to be divergent. ${ }^{71}$

The negotiations with the EU indicate a coordinated approach by the EAC Partner States. However, the Partner States do enter into the agreements individually and where national interest dictate, they can proceed even if contrary to the agreed coordinated position.

\subsection{EAC and Other Regional Communities}

Although the EAC Partner States aim at forming a political federation, this has not prevented the Partner States from joining different regional integration communities (RECS). The Partner States of the EAC are members of various other RECs including COMESA, ${ }^{72}$ SADC $^{73}$ and IGAD. ${ }^{74}$ Indeed Eastern Africa has the largest number of RECS and intergovernmental regional bodies on the continent.

Membership on EAC Partner States in other RECs

\begin{tabular}{llll}
\hline & COMESA & IGAD & SADC \\
\hline Burundi & $*$ & $*$ & \\
Kenya & $*$ & $*$ & \\
Rwanda & $*$ & & \\
South Sudan & & $*$ & \\
Tanzania & $*$ & $*$ & \\
Uganda & $*$ & & \\
\hline
\end{tabular}

71 Kidanka, Christopher. "Tanzania dodges EPA to Protect Industrialisation, budget" The East African July 16, 2006; Bangaba, Julius. "Leaders Urge Review of EU-EAC Trade Deal” The East African July 23, 2016 http://www.theeastafrican.co.ke/news/Leaders-urgereview-of-EAC-EU-trade-deal/2558-3307650-uaooovz/index.html.

72 COMESA-Common Market for Eastern \& Southern Africa see http://www.comesa.int/.

73 SADC- Southern Africa Development Community see http://www.sadc.int/.

74 IGAD - Intergovernmental Authority on Development see http://igad.int/. 
The multiple memberships of the various RECs can result in the duplication of roles and conflicting goals and policies. ${ }^{75}$ Membership of the different RECs can also allow a country to play on the differentials of timings, commitments and tariffs in the various RECs and can be a source of divided loyalty. ${ }^{76}$

It is with this realisation that COMESA-EAC-SADC held a tripartite summit in October 2008 during which it was agreed to establish a tripartite free trade area. ${ }^{77}$ The co-operation is not however between the various RECs but through the member states themselves making commitments.

\subsection{EAC and African Union}

As early as 1980 under the then Organisation for African Unity (OAU), the Lagos Plan of Action for the Economic Development of Africa called for the eventual convergence of various regional trade liberalisation regimes to form the African Common Market. ${ }^{78}$ The commitments in this plan were made concrete in 1991 when African countries signed the Treaty Establishing the African Economic Community (AEC) also known as the Abuja Treaty. ${ }^{79}$ The Abuja Treaty came into operation in 1994 and provides a framework for continental integration. The Abuja Treaty is expected to take shape in six phases over a period of thirty-four years. ${ }^{80}$ The phases require the co-ordination and harmonisation of both tariff and non-tariff systems in the various RECs on the continent with a view to establishing a continental customs union. The various RECS are to be consolidated and then merged into a single block.

The EAC Treaty requires the Partner States to accord special co-operation with the African Union, the United Nations and other international organisations and bilateral and multi-lateral development partners interested in the objectives of the Community. ${ }^{81}$ As part of this effort the EAC enjoys observer status within the African Union. The EAC Secretary General is invited to the

75 African Development Bank. East African Regional Integration Strategy Paper 2011-2015 September 2011.

76 AFRODAD. Regional Integration and Debt in East Africa. High Gloss Prints Harare 2003 p. 23.

77 United Nations Economic Commission for Africa Assessing Regional Integration in Africa VTowards an African Continental Free Trade Area Addis Ababa 2012 p. 21.

78 The Organisation of African Unity. Lagos Plan of Action for Economic Development of Africa 1980-2000. Lagos 1980 paragraph 250 (iv).

79 Treaty Establishing the African Economic Community 1991.

8o Treaty Establishing the African Economic Community 1991.

81 EAC Treaty Article 130(4). 
African Union Summit and is in charge of all relations with the African Union. In 2012, the EAC posted a liaison person to the African Union. The African Union also has a liaison person at the EAC Secretariat.

However, the EAC's activities with the African Union are limited and do not involve actions that would directly bind any of the EAC Partner States. Partner States act independently albeit perhaps in a coordinated manner.

\section{$5 \cdot 7 \quad$ Conclusion}

The EAC does have a limited amount of external competence. The areas where it has been applied is receiving envoys and entering into agreements with development partners. The EAC Partner States have not yielded significant sovereignty to the EAC and instead have adopted a co-ordinated approach to negotiations with third parties. The formal structure for co-ordination, the EAC Joint Trade Negotiation Act is yet to be fully implemented.

This co-ordination approach leaves each individual Partner State entering into multilateral and bilateral agreements as an individual state andwhere domestic interests dictate it, the Partner States will pull away from the coordinated position. However, with political federation as the ultimate goal, the Partner States will have to consider moving beyond mere co-ordination in external relations and grant the EAC greater external competence. 